The Journal of Animal \& Plant Sciences, 30(6): 2020, Page: 1508-1515

ISSN (print): 1018-7081; ISSN (online): 2309-8694

\title{
MOLECULAR CHARACTERIZATION AND MYCOPARASITIC APTITUDE OF INDIGENOUS BIOCONTROL AGENT TRICHODERMA HARZIANUM
}

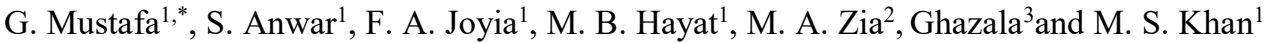 \\ ${ }^{1}$ Centre of Agricultural Biochemistry and Biotechnology (CABB), University of Agriculture Faisalabad, Pakistan. \\ ${ }^{2}$ Department of Biochemistry, University of Agriculture Faisalabad, Pakistan. \\ ${ }^{3}$ Department of Environmental Sciences and Engineering, G.C. University Faisalabad. \\ *Centre of Agricultural Biochemistry and Biotechnology (CABB), University of Agriculture Faisalabad, Pakistan. \\ Corresponding Author's e-mail: drmustafa8@gmail.com
}

\begin{abstract}
Biocontrol agents are always desirous owing to health-conscious attitude and deleterious effects of the chemicals used to control fungal pathogens. In this study, isolates of a biocontrol agent (Trichoderma harzianum) were purified while growing on Potato Dextrose Agar (PDA) containing one $\mathrm{ml}$ of chloramphenicol (1M rexaphenicol). DNA based identification of these fungal isolates was carried out by targeting internal transcribed spacer (ITS) region which is one of the most authenticated markers in molecular systematics. These isolates were also assessed for glucanase production ability, a key indicator of mycoparasitism. Extracellular $\beta$-1,3-glucanase enzyme was purified by gel filtration chromatography using sephadex column G-75. The purified glucanase appeared as a single band on SDS-PAGE, exhibiting molecular weight of approximately $70 \mathrm{kDa}$. Further, purified enzyme was also characterized for various optima in order to appraise its activity. The enzyme was found to be stable and active at a broad range of $\mathrm{pH}(5-8)$ and depicted maximum activity at slightly acidic $\mathrm{pH}$ of 5.5. It showed maximum activity at $25^{\circ} \mathrm{C}$, however, remained remarkably active even at $50^{\circ} \mathrm{C}$ revealing its thermo-tolerance and suitability for industrial usage. Hence, these Trichoderma isolates can not only be used to produce stable glucanase enzyme for industrial applications but can also be used as a proficient biocontrol agent for fungal pathogens.
\end{abstract}

Keywords: Trichoderma harzianum, ITS, $\beta$-1,3-glucanase, purification, characterization, SDS-PAGE.

https://doi.org/10.36899/JAPS.2020.6.0171

Published online August 03,2020

\section{INTRODUCTION}

Biocontrol agents had always been preferred owing to the detrimental consequences of chemical fungicides used for fungal control. Trichoderma harzianum is an ancient and ecologically important mycoparasite that produces valuable hydrolytic enzymes. They are green-spored ascomycetes and are commonly found in rhizospheric soils (Harman et al., 2004). Such avirulent microbes acting as symbionts play their role as plant growth enhancers as well as antagonistic agents against many fungal pathogens i.e. Sclerotinia sclerotiorum, Rhizoctonia solani, Phytophthora megasperma, Gaeumannomyces gramminis, Cylindrocladium scoparium and Sclerotium rolfsii (Perez et al., 2007). Hence, they are of pivotal importance for plant growth as well to protect plants from fungal diseases. Trichoderma harzianum is an important mycoparasitic fungus used as a biocontrol agent to combat many devastating plant pathogens (Ganuza et al., 2019; Steyaert et al., 2004). These biocontrol agents possess extraordinary competence of degrading phytopathogenic hyphae by virtue of numerous hydrolytic enzymes, most importantly chitinases, chitosinases, glucanases and proteases (Benhamou and Chet, 1996).

Glucanases are prominent fungal cell wall degrading enzymes which are found in higher plant tissues, yeast cells, insects' hemolymph and fish as well (Pan et al., 1989). They have been categorized into $\beta-1,3$, $\beta-1,4$ and $\beta-1,6$-glucanases on the basis of glucosidic linkage(s) that they can cleave (Pitson et al., 1993). $\beta$ 1,3-glucanase is also vital for cell survival/integrity and plays an important role in cell division, movement of materials across the cell membranes via plasmodesmata, flowering as well as in the transport of $\beta$-glucans (De La Cruz et al., 1995). Moreover, glucanases are key enzymes involved in mycoparasitism exhibited by Trichoderma sp. (Balasubramanian et al., 2012). Filtered culture of $T$. harzianum was found to contain $\beta$-1,3-glucanase and chitinase. Further, the filtrate was employed to hydrolyze mycelium of a notorious plant pathogen named $S$. rolfsii (El-Katatny et al., 2000).

In addition to mycoparasitic impact, glucanases are valuable for their industrial applications especially in brewery industry in order to reduce viscosity, processing time and precipitation of $\beta$-glucans in the beer. Recently, brewing industry has started using $\beta$-glucanases to carry out better brewing process. Employing T. harzianum for 
industrial scale enzyme production is being practiced since ages (Blumenthal, 2004). Further, presence of $\beta$ glucans in poultry and animal feed is a problem as it makes faeces sticky causing reduced animal performance (Jeroch et al., 1988). $\beta$-1,3-glucanases are also being used to obtain depolymerized fragments with broader usage in pharmaceuticals, food and beverage industry (Kadi and Crouzet, 2008). They are also useful to produce glucooligosaccharides from lichen pustulan and algal paramylon, which may have role in prebiotics (nutraceuticals) and modifier of human immunity related activities (Giese et al., 2011). They are also being employed in medication as are used for the treatment of allergies caused by foodstuff as well as to cure fungal diseases. $\beta$-1,3-glucanases are quite useful for the preparation of protoplasts (Parrado et al., 1996) so can be employed in somatic hybridization or protoplast culture. So this group of enzymes has biotechnological, industrial as well as biomedical applications (McCleary et al., 1988).

Keeping in view the widespread utility of Trichoderma derived glucanases, present study was conducted to isolate, purify and characterize extracellular $\beta$-1,3-glucanase from indigenous Trichoderma harzianum isolates. Further, characteristics of the enzyme are an indicator of mycoparasitic ability of Trichoderma isolates depicting their efficiency to be employed as biocontrol agent.

\section{MATERIALS AND METHODS}

Preparation of potato dextrose agar broth media: Potato starch was prepared by boiling $500 \mathrm{~g}$ of potato infusions in $500 \mathrm{ml}$ of distilled water until the volume remained half. Then it was filtered using muslin cloth to get liquid starch. In order to prepare $1000 \mathrm{ml}$ of PDA, 20 $\mathrm{g}$ of agar and $20 \mathrm{~g}$ of sucrose were dissolved in an appropriate volume of distilled water and $250 \mathrm{ml}$ of liquid starch was added. Then, volume was made up to $1000 \mathrm{ml}$ and $\mathrm{pH}$ was adjusted to 5.5. Then media were autoclaved and one $\mathrm{ml}$ of filter sterilized chloramphenicol (1 $\mathrm{M}$ rexaphenicol) was added in order to check the bacterial growth.

Molecular validation of fungal isolates: Trichoderma strains were characterized using ITS-I (Internal Spacer Region-1) specific primers. Sequence information of the said gene was obtained from Genbank (http://www.ncbi.nlm.nih.gov/). Then Primer-3 online tool was employed to design primers (ITS-1 forward primer, 5'-TCCGTAGGTGAACCTGCGG-3' and ITS-1 reverse primer, 5'-GCTGCGTTCTTCTTCATCGATGC$\left.3^{\prime}\right)$. Amplification was carried out in total of $50 \mu \mathrm{l}$ reaction volume comprising of, $5 \mu \mathrm{l}$ of $10 \mathrm{X} \mathrm{MgCl}_{2}$ free PCR buffer, $5 \mu \mathrm{l}$ of $10 \mathrm{X} \mathrm{MgCl}_{2}, 0.25 \mu \mathrm{l}$ of 2.5 units of Taq polymerase, $0.5 \mu \mathrm{l}$ of $10 \mu \mathrm{M}$ reverse and forward primers, $4 \mu \mathrm{l}$ of $2.5 \mathrm{mM}$ dNTPs and $1.5 \mu \mathrm{l}$ of $100 \mathrm{ng} / \mu \mathrm{l}$ genomic DNA. Thermal cycler profile was as follows: initial denaturation at $94^{\circ} \mathrm{C}$ for 5 minutes followed by 35 cycles of one minute denaturation at $94^{\circ} \mathrm{C}$, one minute primer annealing and extension at $55^{\circ} \mathrm{C}$ and $72^{\circ} \mathrm{C}$ respectively and final extension at $72^{\circ} \mathrm{C}$ for 10 minutes. The resultant amplicons were examined by agarose gel electrophoresis $0.8 \%(\mathrm{w} / \mathrm{v})$ with $10 \mathrm{mg} / \mathrm{ml}$ ethidium bromide.

Production of $\boldsymbol{\beta}-\mathbf{1 , 3}$-glucanase: Mycelia of the indigenous Trichoderma isolates were inoculated in 500 $\mathrm{ml}$ of PDB containing sucrose as carbon source in Erlenmeyer flask. $\mathrm{pH}$ of the medium was adjusted to 5.5 and placed in incubator (Irmeco $\mathrm{GmbH}$, Germany) at $28^{\circ} \mathrm{C}$ for 72 hours in dark at $180 \mathrm{rpm}$ for growth. After filtration, the filtrate was centrifuged at $15000 \mathrm{rpm}$ for 10 min. at $4^{\circ} \mathrm{C}$ in order to get cell free filtrate with maximum clarity. The supernatant (cell free filtrate) referred to as crude enzyme extract was taken into new falcon tube and further employed for isolation and purification of glucanase.

Determination of total protein contents: Total protein contents of the crude extract were quantified by Bradford method (Bradford, 1976) using Bovine Serum Albumin (BSA) as standard.

\section{Isolation and purification of $\beta-1,3$-glucanase}

Protein precipitation using Ammonium sulfate: The crude enzyme was kept in ice for some time and saturated with ammonium sulfate up to $20 \%$. Later on, it was incubated at $4^{\circ} \mathrm{C}$ overnight. Then, it was centrifuged at same temperature for fifteen minutes and at 15,000 rpm. The pellet was kept, and re-precipitation of supernatant was with different concentrations of ammonium sulfate (40, 60, 80, and 100\%). For each concentration of ammonium sulfate, the process of slow dissolution, centrifugation and pellet separation was repeated. All pellets (hereafter termed as crude enzyme) were preserved at appropriate temperature.

Dialysis of crude enzyme: The pellets were resuspended in $0.2 \mathrm{M}$ phosphate buffer $(\mathrm{pH}$ 7.2). For dialysis, a piece of dialysis membrane of proper pore size was cut, filled with resuspended crude enzyme and dialyzed against distilled water (4 times at an interval of 5 hrs) to remove ammonium sulfate.

Sephadex G-75 column based gel filtration chromatography: The gel filtration chromatography of partially purified enzyme was carried out using a glass column of internal diameter $2 \mathrm{~cm}$. It was packed with Sephadex G-75 (Sigma, USA) upto a height of $120 \mathrm{~cm}$ and was equilibrated with $0.2 \mathrm{M}$ phosphate buffer maintaining stable $\mathrm{pH}$ at 7.2. A total of 50 fractions were collected from the column with each fraction of $2 \mathrm{ml}$ at a 
flow rate of $0.5 \mathrm{ml} / \mathrm{min}$. Total protein contents and glucanase activity were determined for each fraction.

Glucanase assay: The activity of Glucanase was assessed by using $250 \mu \mathrm{l}$ of (1\%) carboxy methyl cellulase as substrate dissolved in potassium acetate buffer. Reaction mixture contained 0-125 $\mu$ l glucanase enzyme. It was incubated at $37^{\circ} \mathrm{C}$ for 30 minutes. Then, $1.5 \mathrm{ml}$ Dinitro Salicylic Acid (DNS) reagent was added to stop the reaction (Miller, 1959). The optical density (OD) was recorded using spectrophotometer at $550 \mathrm{~nm}$ wavelength to quantify reducing sugars in the samples as well as in standard samples (containing known concentration of glucose). The amount of enzyme needed to release $1 \mu$ mole of glucose from substrate under given conditions was termed as one unit (IU) of glucanase activity.

Determination of various optimal conditions for purified $\beta$-1,3-glucanase: Finally, the purified glucanase was assayed to evaluate its various optima by examining the effect of different $\mathrm{pH}$ values (4-9) using $0.2 \mathrm{M}$ phosphate buffer, effect of different incubation temperatures $\left(0.0-50^{\circ} \mathrm{C}\right)$, various concentrations of substrate $(0-11 \mathrm{ml}$ of $0.5 \% \mathrm{CMC})$, enzymes $(0-8 \mathrm{ml})$ and thirteen different incubation times were used in different reactions with the difference of six hrs each, to evaluate its impact on the activity of purified $\beta-1,3$-glucanase produced from Trichoderma harzianum. Then enzyme activities for each case were determined under standard assay conditions using $0.5 \% \mathrm{CMC}$ as substrate.

SDS-PAGE analysis: Molecular size of the enzyme was determined using $12 \%$ SDS-PAGE following the protocols given by Laemmli (1970) with certain modifications. Protein samples were heated at $85^{\circ} \mathrm{C}$ for 3 minutes in sample buffer prior to separation on SDSPAGE. Then protein samples were loaded in $12 \%$ polyacrylamide gel and run at constant voltage of $20 \mathrm{~mA}$ for 7-8 hours. Then, gel was stained with Coomassie brilliant blue R and destained with $40 \%$ methanol and $7 \%$ glacial acetic acid.

\section{RESULTS}

Molecular validation of fungal isolates: The selected Trichoderma strains were validated by ITS-1 specific PCR which is one of the most important markers in molecular systematics. Different PCR parameters were optimized to amplify target DNA fragments. A DNA fragment of around $300 \mathrm{bp}$ was amplified (Figure 1), which was sequence characterized for the confirmation of of Trichoderma harzianum isolates.

Isolation and purification of $\beta$-1,3-glucanase from Trichoderma harzianum: After $72 \mathrm{hrs}$ of incubation, enzyme was isolated from the Trichoderma harzianum at log phase of growth. Ammonium sulfate precipitation, dialysis and sephadex G-75 column chromatography was used to purify the enzyme. We collected 50 fractions (2 $\mathrm{ml}$ each) in separate test tubes and subjected to spectrophotometric analysis for measuring optical density which resulted in the detection of proteins in first 25 fractions whereas no protein was detected in rest of the fractions. Among the isolated fractions, $9^{\text {th }}$ fraction appeared to have the highest optical density (1880) (Figure 2).

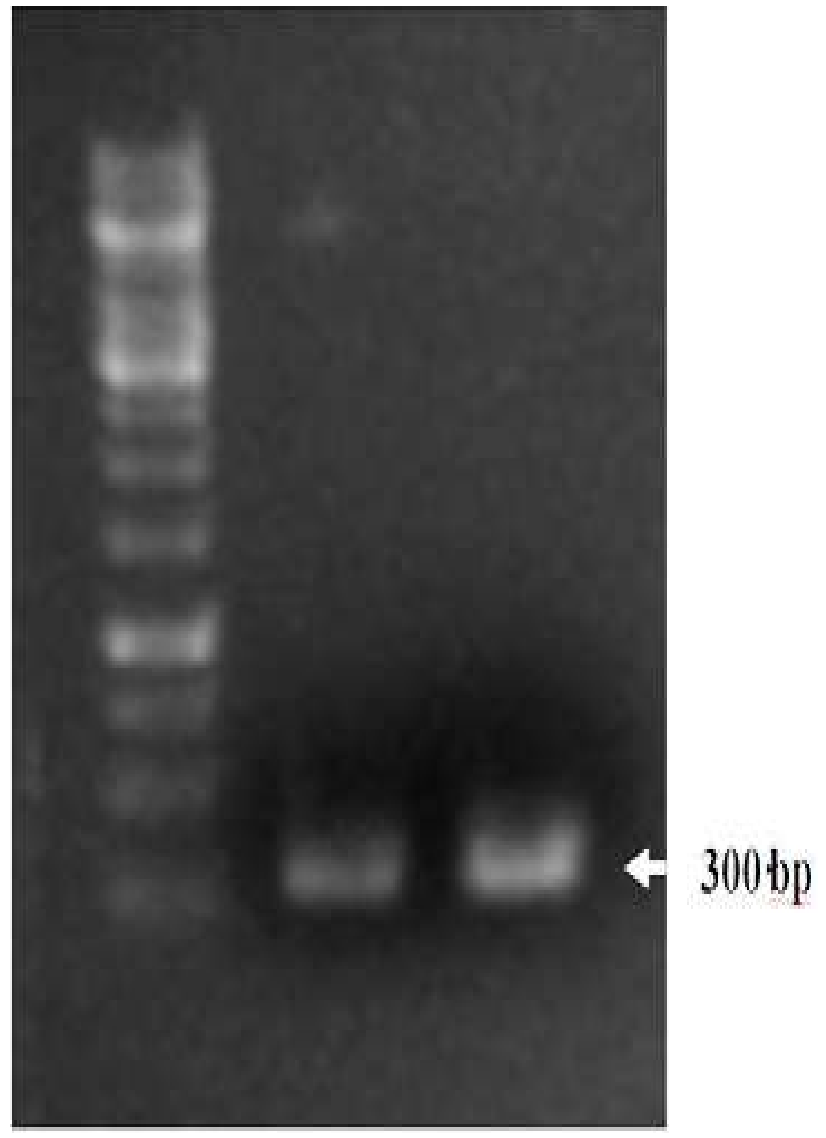

Figure 1. Agarose gel electrophoresis after PCR analysis of Trichoderma isolates using ITS1 primers. Lane 1 represents $1 \mathrm{~Kb}$ DNA ladder, whereas lanes 2 and 3 represent amplification of ITS-1 fragment from fungal isolates. 


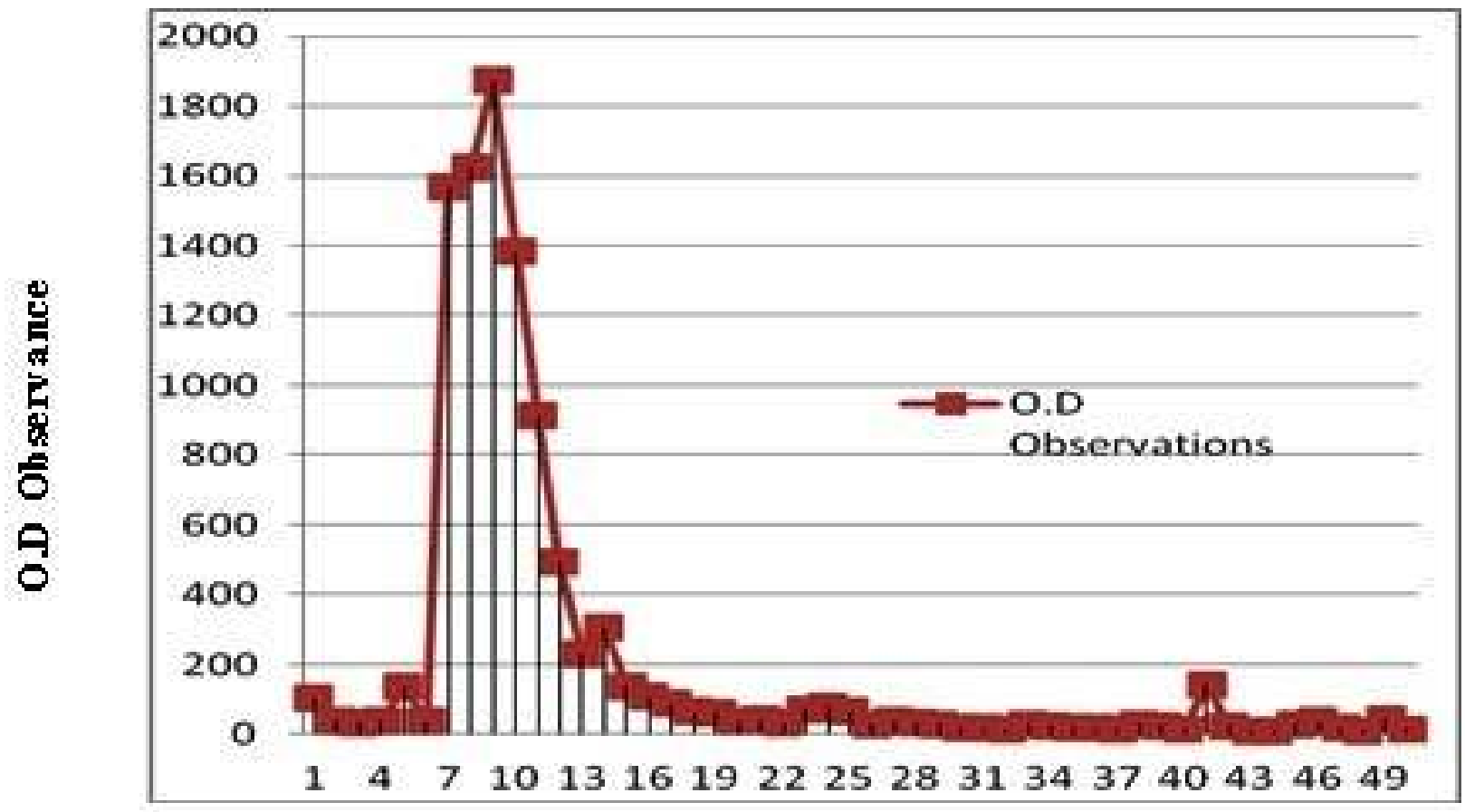

No. of Fractions

Figure 2. Spectrophotometric quantification of various fractions of $\beta$-1,3-glucanase isolated from Trichoderma harzianum.

\section{Characterization of purified $\beta-1,3$-glucanase}

Impact of pH on enzyme activity: The purified enzyme was incubated at different levels of $\mathrm{pH}$ ranging from 48.5 using phosphate buffer of appropriate molarity. Enzyme assay was carried out 15 minutes after the incubation using $0.5 \% \mathrm{CMC}$ as substrate. The absorbance (OD) was measured at $700 \mathrm{~nm}$ which revealed that the purified glucanase enzyme was active at a wide range of $\mathrm{pH}(5-8.5)$ but optimum activity was observed at a $\mathrm{pH}$ value of $5.5(638.7567 \mathrm{U} / \mathrm{ml})$ followed by $339.6306 \mathrm{U} / \mathrm{ml}$ and $443.6343 \mathrm{U} / \mathrm{ml}$ at $\mathrm{pH} 6$ and 6.5 respectively (Figure $3 \mathrm{~A})$. The enzyme activity appeared to be decreased beyond $\mathrm{pH}$ range of 10 .

Impact of temperature on enzyme activity: The enzyme with its substrate was incubated at a range of temperature to determine in order to assess its impact on the activity of isolated glucanase. The isolated enzyme showed maximum activity at $25^{\circ} \mathrm{C}$ with a value of $187.2263 \mathrm{U} / \mathrm{ml}$ followed by $170.8065 \mathrm{U} / \mathrm{ml}$ and 173.5261 $\mathrm{U} / \mathrm{ml}$ at $30^{\circ} \mathrm{C}$ and $35^{\circ} \mathrm{C}$ respectively (Figure $3 \mathrm{~B}$ ). Hence, isolated glucanase appeared to have maximum activity at $25^{\circ} \mathrm{C}$.

Impact of enzyme concentration on its acticity: To determine the optimum glucanase concentration for maximum substrate degradation, numerous dilutions of the enzyme (upto eight-folds) were prepared and mixed with substrate solution of constant concentration. Enzyme-substrate interaction appeared to be increased with increase in enzyme concentration upto $4 \mathrm{ml}$ but thereafter, it appeared to have consistent effects. The best measured enzyme activity was $45.88978 \mathrm{U} / \mathrm{ml}$ at an enzyme concentration of $4 \mathrm{ml}$ per reaction (Figure 3 ).

Effect of substrate concentration on enzyme activity: To determine optimum substrate concentration for highest glucanase activity, eleven different concentrations of the substrate (carboxy methyl cellulose) were tested. The enzyme activity appeared to be increased with increase in substrate concentrations. The maximum values were determined as $646.4545 \mathrm{U} / \mathrm{ml}$ and 638.9549 $\mathrm{U} / \mathrm{ml}$ at $10 \mathrm{ml}$ and $11 \mathrm{ml}$ substrate concentrations respectively whereas further increase in substrate concentration did not show any profound effect on enhanced activity of the enzyme (Figure 3C).

Effect of incubation time on enzyme activity: Impact of incubation time on glucanase activity was determined by preparing enzyme-substrate reaction and incubating them for different time intervals. The maximum activity of enzyme was recorded at incubation time of $18 \mathrm{hrs}$ $(627.3255 \mathrm{U} / \mathrm{ml})$. Thereafter, it appeared to be decreased but increase again at $42 \mathrm{hrs}$ and $60 \mathrm{hrs}(618.5705 \mathrm{U} / \mathrm{ml})$ incubations (Figure 3D). 

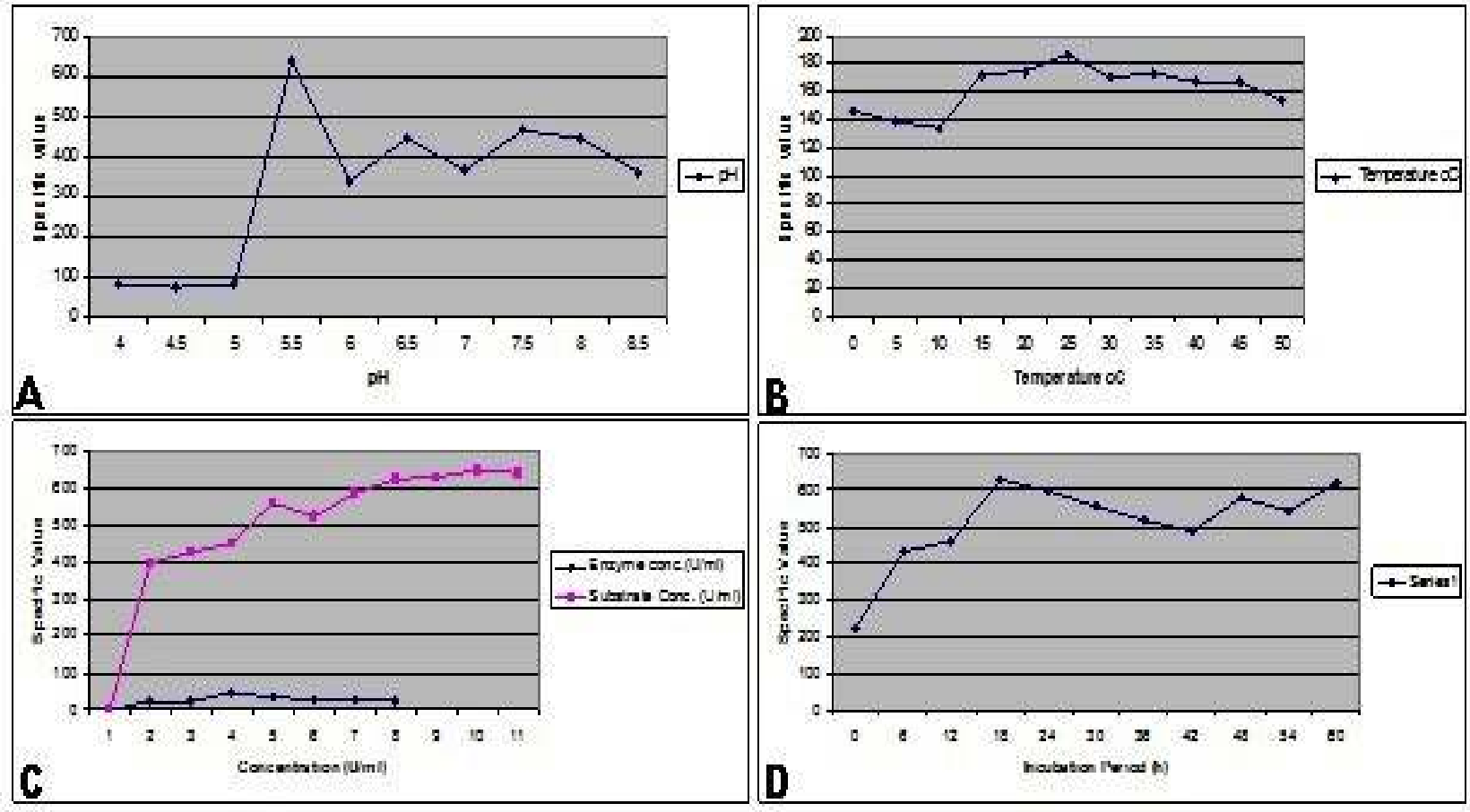

Figure 3. Effect of different conditions on the enzymatic activity of purified $\beta$-1,3-glucanase. (A) Effect of various $\mathrm{pH}$ values on purified enzyme activity which was determined as no. of moles of glucose molecules released. (B) Thermostability of the purified enzyme was determined by measuring the enzyme activity at different levels of temperature. (C) Graphical representation showing impact of enzyme concentration and substrate. (D) Effect of incubation time on $\beta$-1,3-glucanase activity. Maximum activity was determined at $18 \mathrm{hrs}$ of incubation.

Determination of molecular size of enzyme through SDS-PAGE: Purified enzyme was electrophoresed on SDS-PAGE and appeared as single band when run on $12 \%$ SDS-PAGE, showing high purity level of protein having molecular mass of approximately $70 \mathrm{kDa}$ (Figure 4). The gel was stained with coomassie brilliant blue and soaked in methanol, acetic acid and distilled water containing dye solution. Destaining of the gel was carried out using acetic acid solution (Meyer and Lamberts, 1965). The enzyme with specific activity of 618.5705 $\mathrm{U} / \mathrm{ml}$ was used for SDS-PAGE analysis.

\section{DISCUSSION}

Increased productivity of crops is direly needed owing to rapidly increasing population of the world which is expected to rise upto 10 billions by the year 2050. Various biotic stresses including fungal pathogens are significant in this perspective as plant diseases cause more than 12 percent yield losses in agriculture sector (Parvaiz et al., 2018; Fokunang et al., 2004). It further intensifies food shortage in a situation where more than 800 million people, around the globe, are already poorly fed.

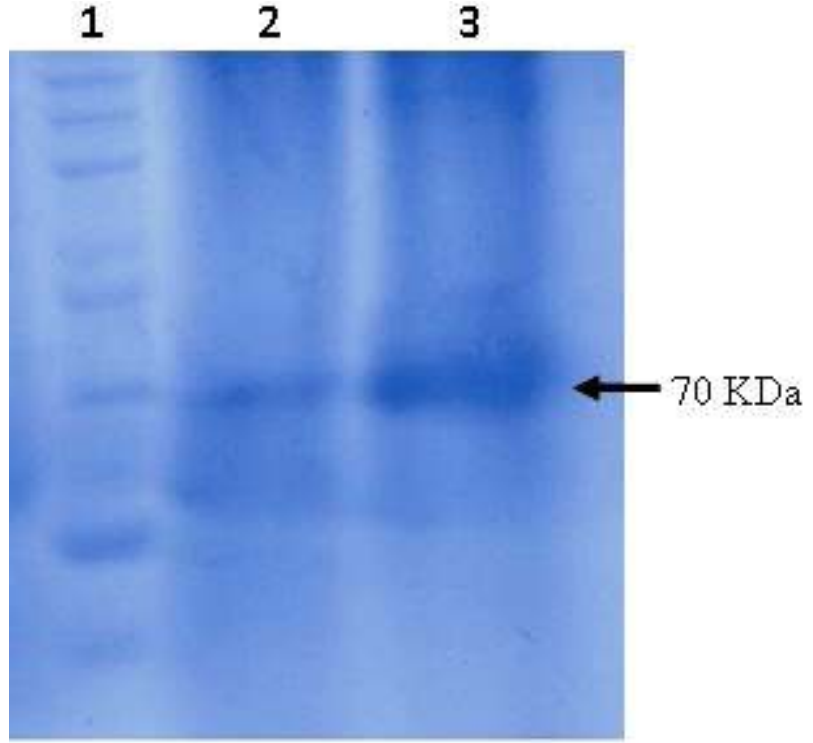

Figure 4. SDS-PAGE analysis of the purified $\beta-1,3-$ glucanase where coomassie brilliant blue was used for the staining of gel. Lane 1 represents $200 \mathrm{kDa}$ protein ladder whereas lanes 2 and 3 represent purified $\beta$-1,3-glucanase enzyme from fungal isolates. 
Fungal diseases are currently being controlled by the application of toxic fungicides which get accumulated in soil, underground water and food. Such accumulations, on one hand, exhibit hazardous effects on human as well as animal health and environment. On the other hand, resistance development in fungal pathogens is also increasing due to abundant and persistent use of fungicides. In this situation, some bio-based alternatives are being explored and several biocontrol agents have been worked out. Besides other biocontrol agents, Trichoderma harzianum has shown consistent control of plant fungal pathogen (Ahmed and Omara, 2018). Trichoderma has evolved various nutritive adaptations including antagonism and mycoparasitism and this has made it a sturdy biocontrol agent. The phenomenon of mycoparasitism involves hydrolytic degradation of host cell wall which is carried out by production of extracellular hydrolytic enzymes i.e. glucanases and chitinases. The degradation of pathogen cell wall permits parasitic hyphae (hyphae of Trichoderma) to penetrate the host cell (Elad, 1997). Such enzymes after purification from Trichoderma have been found highly effective against plant pathogenic fungi than enzymes isolated from other sources (Lorito, 1998).

Many antibiotics and an array of hydrolytic enzymes including glucanases, chitinases, chitosinases and proteases are propsoed to endow the ability of mycoparasitism (Shoresh et al., 2010). Trichodermaderived glucanases, chitinases and other hydrolytic enzymes are considered to be more effective to control fungal diseases, than the enzymes isolated from plants, bacteria or other fungi (Harman et al., 1993; Maximova et al., 2006). Such enzymes are known to elicit plant defence resposne, thus increasing disease tolerance (Kosambo-Ayoo et al., 2011). O'Kennedy et al. (2011) transformed pearl millet genome with $T$. atroviride $\beta-1,3-$ glucanase gene using gene gun. Consequent transgenic lines showed 58\% decrease in S. graminicola infection and the reason was found to be an elevated level of glucanase. The study under-discussion was carried out to explore $\beta$-1,3-glucanase production from Trichoderma harzianum and its characterization for various optima. The optimal temperature for the growth of Trichoderma harzianum as well as for the induction of glucanase gene was found to be $28^{\circ} \mathrm{C}$ (De La Cruz et al., 1995). The similar temperature range was found to be optimum by Sexton et al. (2000). Similarly, Franco et al. (2004) also incubated Trichoderma harzianum strain $\mathrm{T}_{4}$ at $28^{\circ} \mathrm{C}$ to have optimum growth and enzymes production.

As far as effect $\mathrm{pH}$ on enzyme activity is concerned, optimal range varies from species to species nevertheless, it is reported to be 3.0 to 6.0 in most of the cases (Niranjane et al., 2007). Glucanases exhibit maximum enzyme activity at $30^{\circ} \mathrm{C}$ to $55^{\circ} \mathrm{C}(\mathrm{Xu}$ et al., 2006; Peng et al., 2009). Crude exo-glucanase and endoglucanase purified from Aspergillus niger showed optimum $\mathrm{pH} 3.5$ and optimum temperature $30^{\circ} \mathrm{C}$ (Ghori et al., 2012). Likewise, B. subtilis-derived $\beta$-glucanases showed $6.5-9.5$ as optimal $\mathrm{pH}$ and $50^{\circ} \mathrm{C}$ as optimal temperature (Wichitra et al., 2006). In another study, $\beta$ 1,3-glucanase of around $36 \mathrm{kDa}$ was isolated and purified from $T$. harzianum. The enzyme displayed optimum activity at $\mathrm{pH} 5.0$ at $50^{\circ} \mathrm{C}$ (Marco and Felix, 2007). In our studies, $\beta$-1,3-glucanase isolated from the $T$. harzianum was found to be highly active at $25^{\circ} \mathrm{C}$ while it was found stable up to $50^{\circ} \mathrm{C}$. The enzyme was found to be functional at $\mathrm{pH}$ 5.0-8.5 however the best $\mathrm{pH}$ value with highest enzyme activity was found to be 5.5 (De La Cruz et al., 1995). In order to conclude, it is reported that the glucanase enzyme isolated in preset study is tolerant to a broad range of temperatures and a wide range of $\mathrm{pH}$. It depicts its potential to be used as a valuable industrial compound. Hence, Trichoderma strains produced stable $\beta$-1,3-glucanase enzyme envisioning that these strains may be used as a biocontrol agent to control fatal fungal pathogens infecting valuable crops.

Authors' contributions: All of the authors contributed equally in this research

Conflict of interest: Authors have no conflict of interest for this research

\section{REFERENCES}

Ahmed, N. and A.E. Omara (2018). Efficiency of Trichoderma harzianum as a biocontrol agent in combination with humate and chitosan against Meloidogyne incognitaon tomato. Archiv. Phytopathol. 51: 11-12.

Balasubramanian, V., D. Vashisht, J. Cletus and N. Sakthivel (2012). Plant $\beta$-1,3-glucanases: their biological functions and transgenic expression against phytopathogenic fungi. Biotech. Lett. 34(11): 1983-1990.

Benhamou, N. and I. Chet (1996). Parasitism of sclerotia of Sclerotium rolfsii by Trichoderma harzianum: ultrastructural and cytochemical aspects of the interaction. Phytopathol. 86(4): 405-416.

Blumenthal, C.Z. (2004). Production of toxic metabolites in Aspergillus niger, Aspergillus oryzae and Trichoderma reesei: justification of mycotoxin testing in food grade enzyme preparations derived from the three fungi. Regul. Toxicol. Pharmacol. 39(2): 214-228.

Bradford, M.M. (1976). A rapid and sensitive method for quantitation of microgram quantities of protein utilizing the principle of protein-dye binding. Annal. Biochem. 72(1-2): 248-254.

De La Cruz, J., J.A. Pintor-Toro, T. Benitez, A. Llobel and L.C. Romero (1995). A novel endo $\beta$-1,3glucanase, BGN 13.1, involved in the mycoparasitism of Trichoderma harzianum. J. Bacteriol. 177(23): 6937-6945. 
Elad, Y. (1997). Responses of plants to infection by Botrytis cinerea and novel means involved in reducing their susceptibility to infection. Biol. Rev. 72(3): 381-422.

El-Katatny, M.H., W. Somitsch, K.H. Robra, M.S. ElKatatny and G.M. Gubitzn (2000). Production of chitinase and $\beta$-1,3-glucanase by Trichoderma harzianum for control of the phytopathogenic fungus Sclerotium rolfsii. Food Tech. Biotechnol. 38(3): 173-180.

Fokunang, C.N., J.L. Beynon, K.A. Watson, N.H. Battey, J.M. Dunwell and E.A. Tembe-Fokunang (2004). Advancement in genetic modification technologies towards disease resistance and food crop production. Biotechnol. 3(1):1-20.

Franco, P.F., H.M. Ferreira and E.X.F. Filho (2004). Production and characterization of hemicellulase activities from Trichoderma harzianum strain T4. Biotechnol. Appl. Biochem. 40(3): 255-259.

Ganuza, M., N. Pastor, M. Boccolini, J. Erazo, S. Palacios, C. Oddino, M.M. Reynoso, M. Rovera, A.M. Torres (2019). Evaluating the impact of the biocontrol agent Trichoderma harzianum ITEM 3636 on indigenous microbial communities from field soils. J. Appl. Microbiol. 126(2):608-623.

Ghori, M.I., S. Ahmed, M.A. Malana and A. Jamil (2012). Kinetics of exoglucanase and endoglucanase produced by Aspergillus niger NRRL 567 (2012). Kinetics of exoglucanase and endoglucanase produced by Aspergillus niger NRRL 567. Afri. J. Biotechnol. 11(28): $7227-$ 7231.

Giese, E.C., R.F.H. Dekker, A.M. Barbosa, M.L.C. da Silva and R. da Silva (2011). Production of $\beta-$ (1,3)-glucanases by Trichoderma harzianum Rifai: optimization and application to produce gluco-oligosaccharides from paramylon and pustulan. Fermentat. Technol. 1(1):1-5.

Harman, G.E., C.K. Hayes, M. Lorito, R.M. Broadway, A. Di Pietro, C. Peterbauer and A. Tronsmo (1993). Chitinolytic enzymes of Trichoderma harzianum: purificarion of chitobiosidase and endochitinase. Phytopathol. 83(3): 313-318.

Harman, G.E., C.R. Howell, A. Viterbo, I. Chet and M. Lorito (2004). Trichoderma speciesopportunistic, avirulent plant symbionts. Nat. Rev. Microbiol. 2(1): 43-56.

Jeroch, H., M. Aboud, K.H. Engerer and G. Grebhsrdt (1988). Evaluation of an enzyme preparation containing $\beta$-glucanase in broiler fattening rations based on barley. Arch. Anim. Nutrit. 38: 399-404.

Kadi, N. and J. Crouzet (2008). Transglycosylation reaction of endoxylanase from Trichoderma longibrachiatum. Food Chem. 106(2): 466-474.
Kosambo-Ayoo, L.M., M. Bader, H. Loerz and D. Becker (2011). Transgenic sorghum (Sorghum bicolor L. Moench) developed by transformation with chitinase and chitosanase genes from Trichoderma harzianum expresses tolerance to anthracnose. Afri. J. Biotechnol. 10(19): 36593670 .

Laemmli, U.K. (1970). Cleavage of structural proteins during the assembly of the head of bacteriophage T4. Nature 227(5259): 680-685.

Lorito, M. (1998). Chitinolytic enzymes and their genes. In: Trichoderma and Gliocladium. pp: 73-99. G.E. Harman and C.P. Kubicek (eds.). Taylor and Francis, London.

Marco, J.L.D. and C.R. Felix (2007). Purification and characterization of a $\beta$-Glucanase produced by Trichoderma harzianum showing biocontrol potential. Braz. Arch. Biol. Techn. 50(1): 21-29.

Maximova, S.N., J.P. Marelli, A. Young, S. Pishak, J.A. Verica and M.J. Guiltinan (2006). Overexpression of a cacao class I chitinase gene in Theobroma cacao L. enhances resistance against the pathogen, Colletotrichum gloeosporioides. Planta 224(4): 740-749.

McCleary, B.V., I. Shameer and M. Glennie-Holmes (1988). Measurement of 1-3,1-4- $\beta$-D-glucan. Meth. Enzymol. 160: 545-551.

Meyer, T.S. and L.B. Lamberts (1965). Use of coomassie brilliant blue R250 for the electrophoresis of microgram quantities of parotid saliva proteins on acrylamide-gel strips. Biochim. Biophys. Acta. 107(1): 144145.

Miller, G.L. (1959). Use of DNS reagent for determination of reducing sugars. Annal. Chem. 31(3): 426-428.

Niranjane, A.P., P. Madhou and T.W. Stevenson (2007). The effect of carbohydrate carbon sources on the production of cellulase by Phlebia gigantean. Enzyme Microbial. Technol. 40(6): 1464-1468.

O'Kennedy, M.M., B.G. Crampton, M. Lorito, E. Chakauya, W.A. Breese, J.T. Burger and F.C. Botha (2011). Expression of a $\beta$-1,3-glucanase from a biocontrol fungus in transgenic Pearl millet. S. Afr. J. Bot. 77(2): 335-345.

Parvaiz, A., G. Mustafa and F.A. Joyia (2018). Understanding invasive plant mycoparasites and their remedy through advanced molecular approaches. Pakistan J. Phytopathol. 31: 02.

Pan, S.Q., X.S. Ye and J. Kuc (1989). Direct detection of $\beta$-1,3-glucanase isozymes on polyacrylamide electrophoresis and isoelectrofocusing gels. Annal. Biochem. 182(1): 136-140.

Parrado, J., P.R. Escuredo, F. Conejero-Lara, M. Kotik, C.P. Ponting, J.A. Asenjo and C.M. Dobson (1996). Molecular characterisation of a 
thermoactive $\beta$-1,3-glucanase from Oerskovia xanthineolytica. Biochim. Biophys. Acta. 1296(2): 145-151.

Peng, Y., Z.M. Chi, X.H. Wang and J. Li (2009). Purification and molecular characterization of exo-beta-1,3-glucanases from the marine yeast Williopsis saturnus WC91-2. Appl. Microbiol. Biotechnol. 85(1): 85-94.

Perez, L., R. Polanco, J.C. Rios, J. Montealegre, L. Valderrama, R. Herrera and X. Besoain (2007). The increase in endochitinases and $\beta-1,3-$ glucanases in the mutant Th650-NG7 of the Trichoderma harzianum Th650, improves the biocontrol activity on Rhizoctonia solani infecting tomato. IOBC WPRS Bulletin 30(6/2): 135.

Pitson, S.M., R.J. Seviour and B.M. Mcdougall (1993). Noncellulolytic fungal $\beta$-1,3-glucanases: Their physiology and regulation. Enzyme Microb. Technol. 15(3): 178-192.

Sexton, A.C., M. Paulsen, J. Woestemeyer and B.J. Howlett (2000). Cloning, characterization and chromosomal location of three genes encoding host-cell-wall-degrading enzymes in Leptosphaeria maculans, a fungal pathogen of brassica spp. Gene 248(1-2): 89-97.

Shoresh, M., F. Mastouri and G.E. Harman (2010). Induced systemic resistance and plant responses to fungal biocontrol agents. Annu. Rev. Phytopathol. 48(1): 21-43.

Steyaert, J.M., A. Stewart, M.V. Jaspers, M. Carpenter and H.J. Ridgway (2004). Co-expression of two genes, a chitinase (chit42) and proteinase (prb1) implicated in mycoparasitism by Trichoderma hamatum. Mycologia. 96(6): 1245-1252.

Wichitra, L., S. Pranom and P. Souwalak (2006). Purification, characterization and synergistic activity of $\beta$-1,3-glucanase and antibiotic extract from an antagonistic Bacillus subtilis NSRS 8924 against rice blast and sheath blight. Enz. Micro. Technol. 38: 990-997.

Xu, Z., M.C. Shih and J.E. Poulton (2006). An extracellular exo-beta-(1,3)-glucanase from Pichia pastoris: purification, characterization, molecular cloning and functional expression. Protein Expr. Purif. 47(1): 118-127. 